\title{
Vegetation Database of the Volga and the Ural Rivers Basins
}

\author{
Tatiana Lysenko, Olga Kalmykova \& Anna Mitroshenkova
}

\begin{abstract}
In 2004, researchers from the Department of phytodiversity of the Institute of the Ecology of the Volga River Basin of the Russian Academy of Sciences (Togliatti), the chair of botany of Samara State Academy of Social Sciences and Humanities (Samara) and the Department of the biogeography and biodiversity monitoring of the Institute of Steppe UB RAS (Orenburg) started working on the development of the Vegetation Database of the Volga and the Ural Rivers Basins (GIVD ID EU-RU-003). This database uses TURBOVEG. At present the database contains data on plant communities of forest-steppe and steppe zones within Ulyanovsk, Samara, Saratov, Orenburg, Saratov and Astrachan regions. Information is collected in two groups with separate data on geobotanical relevés and on the syntaxa uniting these relevés. In the first case, each geobotanical relevé includes the following parameters: the species composition with projective cover for each species of plants; total projective cover; plot size; ecotope and location, where the relevé was made; information on publication of the relevé (the reference, table number, relevé number in the table); syntaxon which the relevé belongs to; its position in the SynBioSys Europe syntaxa system; geographical coordinates. In the second case, each syntaxon is provided with its name, position in the SynBioSys Europe syntaxa system, number of relevés and the permanence of each species. Currently, the database has information of halophytic (Thero-Salicornietea, Festuco-Puccinellietea), steppe (FestucoBrometea), meadow (Phragmito-Magnocaricetea, Molinio-Arrhenetheretea) vegetation and karst relief vegetation (Festuco-Brometea, Querco-Fagetea, Galio-Urticetea, Trifolio-Geranietea sanguinei) in the Volga and the Ural River Basins within forest-steppe and steppe zones, and includes results of our own research activities (since 1994) and data from literature sources (since 1968). The data is collected in each of the institutions mentioned above, and then the data is exchanged and summarized. The database is connected toEuropean Syntaxonomical Biological System SynBioSys Europe (http://www.synbiosys.alterra.nl/synbiosyseu) where the data on 917 published relevés and 127 syntaxa has been currently sent to.
\end{abstract}

Keywords: Ural River Basin; Volga River Basin.

\section{Vegetation Database of the Volga and the Ural Rivers Basins}

Scope: The Database has information of halophytic (Thero-Salicornietea, Festuco-Puccinellietea), steppe (Festuco-Brometea), meadow (Phragmito-Magnocaricetea, Molinio-Arrhenetheretea) vegetation and karst relief vegetation (Festuco-Brometea, Querco-Fagetea, Galio-Urticetea, Trifolio-Geranietea sanguinel) in the Volga and the Ural River Basins within forest-steppe and steppe zones.

Status: ongoing capture

Period: 1968-2011

Database manager(s): Tatiana Lysenko (Itm2000@mail.ru)

Owner: IEVB RAS

IS UB RAS (private)

Web address: $[\mathrm{NA}]$

Availability: according to a specific agreement

Database format(s): TURBOVEG, Excel

Online upload: no

Online search: no

Publication: Lysenko T., Mitroshenkova A., Kalmykova O. Vegetation Database of the Volga and the Ural Rivers Basins // Vegetation Databases and Climate Change // Book of Abstracts of the 9th Int. Meeting on Vegetation Databases, Hamburg, 24-26 February 2010 P. 74.

Plot type(s): normal plots

Plot-size range: $0.1-100 \mathrm{~m}^{2}$

Non-overlapping plots: 4,500

Estimate of existing plots: [NA]

Completeness: [NA]

Total plot observations: 4,500

Number of sources: 4500

Valid taxa: $[N A]$

Countries: RU: $100.0 \%$

Forest: [NA] — Non-forest: [NA]

Guilds: all vascular plants: $90 \%$; only trees and shrubs: $10 \%$; bryophytes (terricolous or aquatic): $10 \%$; lichens (terricolous or aquatic): $5 \%$; algae (terricolous or aquatic): $1 \%$

Environmental data: altitude: $10 \%$; slope aspect: $70 \%$; slope inclination: $70 \%$; microrelief: $90 \%$; soil depth: $90 \%$; surface cover other than plants (open soil, litter, bare rock etc.): $80 \%$

Performance measure(s): cover: $100 \%$; other: $10 \%$

Geographic localisation: GPS coordinates (precision $25 \mathrm{~m}$ or less): $95 \%$; point coordinates less precise than GPS, up to $1 \mathrm{~km}: 5 \%$

Sampling periods: 1960-1969: 1.0\%; 1970-1979: 1.0\%; 1980-1989: 1.0\%; 1990-1999: 30.0\%; 2000-2009: 62.0\%; 2010-2019: 5.0\%

Information as of 2012-07-12; further details and future updates available from http://www.givd.info/ID/EU-RU-003 
Tatiana Lysenko* (1tm2000@mail.ru)

Department of the Problems of Phytodiversity, Institute of the Volga River Basin RAS, Komzin str. 10, 445003 Togliatti, RUSSIA

Olga Kalmykova (o.k.81@ list.ru)

Department of the Biogeography and Biodiversity Monitoring, Institute of Steppe UB RAS, Pionerskaya str. 11, 460000 Orenburg, RUSSIA

Anna Mitroshenkova (mds_mitri4@mail.ru)

Chair of Botany, Samara State Academy of Social Sciences and Humanities, Antonova-Ovseenko str. 26, 443090 Samara, RUSSIA

*Corresponding author 